Titih Huriah ${ }^{1}$, Ika Fauziyah Rahmawati ${ }^{1}$

${ }^{1}$ Universitas Muhammadiyah Yogyakarta

Corresponding Author: Titih Huriah

Email: titih.huriah@umy.ac.id \section{Description of the Characteristics of
Nutritional Status Based on Food Intake Description of the Characteristics of
Nutritional Status Based on Food Intake in School-Age Children}

$\begin{array}{ll}\text { Article Info } & \\ \text { Online } & : \text { http://journal.umy.ac.id/index.php/ijnp } \\ \text { ISSN } & : 25484249 \text { (Print) } \\ & : 2548592 X \text { (Online) } \\ \text { DOI } & : 10.18196 / \text { ijnp.3299 }\end{array}$

Background: One of the factors that influence nutritional status is food intake. Imbalance of food intake in school-age children causes nutritional problems occurring due to the decline in the immune system.

Objective: This study aims to determine the description of the characteristics of nutritional status based on the school-age children's intake of food.

Method: This study used a cross-sectional design with a random sample size of 84 students from grade 1 to grade 6 in Sonosewu Bantul Elementary School. The instruments used in the study were school-age, weight scales, and food records. The variable in this study was the description of nutritional status characteristics based on food intake in school-age children. The data analysis used frequency distribution.

Result: The results showed that 57 school-age children (67.85\%) had a normal nutritional status. Respondents in this study had less carbohydrate intake ( $n=64 ; 76,2 \%)$, more protein intake ( $n=47 ; 56 \%)$, less fat intake ( $n=56 ; 66,7 \%)$, less vitamin intake ( $n=49 ; 58,3 \%)$, less mineral intake $(n=84,100 \%)$. In children with normal nutritional status, the researcher found that 34 (40,5\%) had more protein intake. Conclusion: The majority of school-age children in Sonosewu Bantul Elementary School had normal nutritional status with excessive protein intake. However, their nutrient intake in the form of calories, carbohydrates, fats, minerals, and vitamins were less. This fact may have an impact on the growth and development of school-age children.

Keywords: Food Intake; Nutrition, Nutrition Status; School-Age Children

\section{INTRODUCTION}

School-age children are individuals who are in the age range of 7 to 12 years (Marisa \& Nuryanto, 2014). Indonesia Health Profile of 2018 states that the prevalence of the number of school-age children in Indonesia is quite a lot, namely 28.1 million children (Ministry of Health of the Republic of Indonesia, 2019). The age of school-age children has progressed the development of skills so that schoolage children need optimal and balanced nutrition. Proper nutrition is also needed for children to concentrate, brain growth, and improve memory, which can affect the quality of human resources in the future. At this time, adequacy and nutritional balance is an essential factor that must be considered by parents as a foundation for children's health (Irmilia, Herlina, Hasneli, 2015; Hidayati, 2012; Soetjiningsih \& Ranuh, 2014).

World Health Organization (WHO) in 2016 reported the prevalence of malnutrition status in children in the world reached $14.0 \%$ or around 94.5 million children, the prevalence of fat nutritional status reached $6.0 \%$ or around 40.6 million children, and 


\section{NUNRSING \\ PRACTICES}

low prevalence reached $22.9 \%$ or around 154.8 million. Basic Health Research Data (RISKESDAS) in 2013 reported that the problem of nutritional status based on BMI/A in children aged 5-12 years was divided into two results (Ministry of Health of the Republic of Indonesia, 2013). The first was the prevalence of thinness of $11.2 \%$, which consisted of $4.0 \%$, very thin, and $7,2 \%$ are thin, and the second was the prevalence of fat by $18.8 \%$, consisting of $10.8 \%$ fat and $8.8 \%$ very fat (obese). Meanwhile, the prevalence of nutritional status problems in children aged $5-12$ years based on height was $30.7 \%$, which consisted of $12.3 \%$ very short and $18.4 \%$ short. In addition, other nutritional problems that often occur in school-age children are nutritional deficiency anemia, lodine Deficiency Disorders (IDD), and dental caries (Adriani \& Wirjatmadi, 2012).

Problems with nutritional status can be caused by two factors, namely, directly and indirectly. Direct factors are such as food intake and infectious diseases. Indirect factors are such as the family economy, parenting, closest health services, and sanitation (Alatas, 2011 in Latifah, 2015).

School-age children have begun to possess an active consumer characteristic that is starting to choose foods that are only preferred (Iklima, 2017; Karaki, Kundre, \& Karundeng, 2016). In Indonesia, most school-age children live in environments that offer a lot of high-energy foods that are cheap, tasty, and have little nutritional content, such as foods and drinks that contain large portions of sugar (Warkentin, Mais, Latorre, Carnell, \& Taddei, 2018). It causes school-age children to eat less fibrous foods, such as fruits and vegetables, and tend to consume fast food frequently (Utari, Ernalia, \& Suyanto, 2016).

The recommended proportion of energy and carbohydrates, protein, and fat in children aged 418 years is $55 \%, 15 \%$, and $20 \%$ (Rahman, Dewi, \& Bohari, 2017). Food consumption that does not vary for food intake is not in accordance with the Recommended Dietary Allowances (RDAs), and the imbalanced food intake in school-age children can result in a child experiencing a decrease in endurance, making it vulnerable to disease and experiencing nutritional status problems (Utari,
Ernalia, \& Suyanto, 2016). It makes children a group that is vulnerable to nutritional problems. The purpose of this study is to determine the nutritional status based on food intake in school-age children.

\section{METHOD}

This type of research was a quantitative study with a cross-sectional design to reveal the characteristics of nutritional status based on the food intake of school-age children. The picture studied was a picture of the nutritional status of school-age children, a description of nutrient intake, and an overview of nutritional status based on calorie intake. The population in this study were students of first grades until sixth grades in Sonosewu Bantul Elementary School, totaling 322 people who were included in the inclusion criteria. The sample in the study was calculated using the Slovin's formula and anticipated dropout. The calculation results obtained 84 respondents of school-age children selected by simple random sampling.

This research was conducted in November 2018 February 2019. The research variable was a description of the characteristics of nutritional status based on food intake in school-age children. The instruments used in this study were microtoise for the measurement of the height of school-age children, the scales to measure the weight of schoolage children, and food records to see the intake of school-aged children. Microtoise and scales have been calibrated at the Metrology Center, and the food record is a standardized research instrument from Instruments for Clinical Health Research (Varricchio, Frank-Stromborg, \& Olsen, 2004). The analysis of research used frequency distribution.

\section{RESULTS}

This study involved 84 respondents from students and parents of Sonosewu Bantul Elementary School students. The research data on the characteristics of the respondents used to find out the general description of the respondents in this study were the nutritional status of the respondents and the gender demographic data of the research respondents, with the following explanation: 
Table 1. Distribution of respondent characteristics based on age, gender, and nutritional status $(n=84)$

\begin{tabular}{lc}
\hline Characteristics of Respondents & $f(\%)$ \\
\hline Age & \\
$-\quad 7$ - 9 years & $44(52.4)$ \\
- 10 - 12 years & $40(47.6)$ \\
Gender & \\
- Male & $34(40.5)$ \\
- Female & $50(59.5)$ \\
Nutritional Status & \\
- Thin & $2(2.4)$ \\
- Normal & $57(67.85)$ \\
- Fat & $12(14.28)$ \\
- Obese & $13(15.47)$ \\
\hline
\end{tabular}

Table 1 shows that the frequency of the 7-9-year-old group of children is more than the group of 10-12year-old children with the majority is female and with the normal nutritional status.

Table 2. Distribution of Frequency of Nutrient Intake (Carbohydrate, Protein, Fat, Vitamins, and minerals) in Elementary Students $(n=84)$

\begin{tabular}{lc}
\hline \multicolumn{1}{c}{ Nutrient Intake } & $\mathrm{f}(\%)$ \\
\hline Carbohydrate Intake & $64(76.2)$ \\
- Less & $9(10.7)$ \\
- Enough & $11(13.1)$ \\
- More & \\
Protein intake & $34(40.5)$ \\
- Less & $3(3.6)$ \\
- Enough & $47(56)$ \\
- More & \\
Fat Intake & $56(66.7)$ \\
- Less & $1(1.2)$ \\
- Enough & $27(32.1)$ \\
- More & \\
Vitamin Intake & \\
- Less & $49(58.3)$ \\
- Enough & $2(2.4)$ \\
- More & $33(32.1)$ \\
Mineral Intake & \\
- Less & $84(100)$ \\
\hline
\end{tabular}

Based on Table 2, the majority of respondents' carbohydrate intake is in less category with 64 students (76.2\%). Meanwhile, for protein intake, most of the respondents are in more category, namely 47 students (56\%). Then, for the data on fat and vitamin intake, most of the respondents have less fat and vitamin intake, consisting of fat with 56 students (66.7\%) and vitamins with 49 students (58.3\%). Also, for mineral intake, all respondents have less mineral intake.
Table 3. Cross-tabulation of nutrients (carbohydrates, proteins, fats, vitamins, and minerals) on the nutritional status of children

\begin{tabular}{ccccccccc}
\hline \multirow{2}{*}{ Calorie } & \multicolumn{1}{c}{ Thin } & \multicolumn{9}{c}{ Normal } & \multicolumn{2}{c}{ Fat } & \multicolumn{2}{c}{ Obese } \\
Intake & \multicolumn{1}{c}{ Thitional Status } & $\%$ & $\mathrm{f}$ & $\%$ & $\mathrm{f}$ & $\%$ & $\mathrm{f}$ & $\%$ \\
\hline Less & 1 & 1.2 & 40 & 47.6 & 8 & 9.5 & 8 & 9.5 \\
Enough & 0 & 0 & 9 & 10.7 & 1 & 1.2 & 0 & 0 \\
More & 1 & 1.2 & 8 & 9.5 & 3 & 3.6 & 5 & 6 \\
\hline
\end{tabular}

Based on Table 3, the results show that, of the 84 respondents, most of the respondents have less carbohydrate intake of 45 students $(53.6 \%)$ that occur in respondents with normal nutritional status. Meanwhile, for protein intake, most of them have more protein intake, namely 34 students $(40.5 \%)$, and experienced by respondents with normal nutritional status. Respondent data, which has an intake of fat, vitamins, and minerals, also mostly have less intake for fat, vitamins, and minerals.

Table 4. Cross-tabulation of calorie intake on nutritional status of elementary school students $(n=84)$

\begin{tabular}{|c|c|c|c|c|c|c|c|c|}
\hline \multirow{3}{*}{$\begin{array}{l}\text { Nutrient } \\
\text { Intake }\end{array}$} & \multicolumn{8}{|c|}{ Nutritional Status } \\
\hline & \multicolumn{2}{|c|}{ Thin } & \multicolumn{2}{|c|}{ Normal } & \multicolumn{2}{|c|}{ Fat } & \multicolumn{2}{|c|}{ Obese } \\
\hline & f & $\%$ & f & $\%$ & $\mathrm{f}$ & $\%$ & $f$ & $\%$ \\
\hline \multicolumn{9}{|c|}{ Carbohydrate Intake } \\
\hline Less & 1 & 1.2 & 45 & 53.6 & 9 & 10.7 & 9 & 10.7 \\
\hline Enough & 0 & 0 & 5 & 6 & 1 & 1,2 & 3 & 3.6 \\
\hline More & 1 & 1.2 & 7 & 8,3 & 2 & 2.4 & 1 & 1.2 \\
\hline \multicolumn{9}{|c|}{ Protein Intake } \\
\hline Less & 1 & 1.2 & 22 & 26.2 & 4 & 4.8 & 7 & 8.3 \\
\hline Enough & 0 & 0 & 1 & 1,2 & 2 & 2,4 & 0 & 0 \\
\hline More & 1 & 1.2 & 34 & 40.5 & 6 & 7.1 & 6 & 7.1 \\
\hline \multicolumn{9}{|c|}{ Fat Intake } \\
\hline Less & 2 & 2.4 & 38 & 45.2 & 8 & 9.5 & 8 & 9.5 \\
\hline Enough & 0 & 0 & 1 & 1.2 & 0 & 0 & 0 & 0 \\
\hline More & 0 & 0 & 18 & 21.4 & 4 & 4.8 & 5 & 6 \\
\hline \multicolumn{9}{|c|}{ Vitamin Intake } \\
\hline Less & 1 & 1.2 & 35 & 41.7 & 8 & 9.5 & 5 & 6 \\
\hline Enough & 0 & 0 & 1 & 1.2 & 1 & 1.2 & 0 & 0 \\
\hline More & 1 & 1.2 & 21 & 25 & 3 & 3.6 & 8 & 9.5 \\
\hline \multicolumn{9}{|c|}{ Mineral Intake } \\
\hline Less & 2 & 2.4 & 57 & 67.9 & 12 & 14.3 & 13 & 15.5 \\
\hline
\end{tabular}

Based on Table 4, most respondents with normal nutritional status have less intake of carbohydrates, fats, vitamins, and minerals, and have more intake for protein. 


\section{NURSTING \\ PRACTICES}

\section{DISCUSSION}

Normal nutritional status can occur if the child gets adequate and proper nutrition and is used efficiently to enable physical growth, brain development, workability to reach optimal health levels. Other factors that influence nutritional status are the level of maternal knowledge, the level of parental education, the number of family members which causes a reduction in the amount of food consumed, parental income, and improper parenting (Lestari, Ernalia, \& Restuastuti, 2016; Siregar, Ernalia, \& Restuastuti, 2016). School-age children are considered to have normal nutritional status if the z-score of BMI/A is between - 2 SD to 1 $\mathrm{SD}$, and if they have a z-score of more or less than that number, they are considered to have nutritional status problems.

Based on the results of the study, it found that, of the 84 respondents, most respondents had less carbohydrate intake of 64 students $(76.2 \%)$ In this study, the carbohydrate intake of students who were often consumed were white rice, porridge, and "Nasi Uduk" (influence rice). White rice has the highest carbohydrate content; however, students often skipped breakfast and reduced the amount of carbohydrate intake. It was because children were afraid to arrive late, and they started thinking about their appearance.

Carbohydrates have the primary function as a provider of the main energy intake in the body. The average carbohydrate requirement needed by school-age children is around $50 \%-60 \%$ of the nutritional needs (RDA). Carbohydrate requirements for children aged 7-9 years are 254 grams, for males aged $10-12$ years are 289 grams, and for females aged 10-12 years are 275 grams (Hardiansyah, Riyadi, \& Napitupulu, 2013). Factors that can be the cause of the lack of carbohydrate intake are lack of parental knowledge and the amount of carbohydrate intake consumed by students that are not in accordance with the needs of children, and the child's excessive preference for a type of food and lack of energy consumption will result in the body not getting all the nutritional status that is needed (Rauf, Dewi, \& Syafei, 2015; Utari, Ernalia, \& Suryanto, 2016).
For the protein intake in school-age children, the majority had excess protein intake. It can be caused by the distribution of protein foods consumed by respondents were quite good. In this study, students more often consumed foods, such as tempe, tofu, and eggs, as a source of their protein intake. Tempe is a processed soybean that has a high enough animal protein content. The body needs protein for the development of body and brain, growth, immunity, and muscle growth. At one gram of protein is the same as containing four calories The contribution of energy needs in protein in children aged $5-18$ years is $15 \%$ of the body's needs (Hardiansyah \& Napitupulu, 2012). The need for protein intake in children aged $7-9$ years is 49 grams, for female aged $10-12$ years is 60 grams, and for male aged $10-12$ years is 56 grams (Hardiansyah \& Napitupulu, 2012). Excessive protein causes deamination/release of amino groups ( $\mathrm{NH} 2)$ from amino acids. Nitrogen will be removed from the body, and the remaining carbon bonds will be converted into acetyl CoA. Acetyl CoA can, then, be synthesized into triglycerides through the process of lipogenesis. Therefore, excess protein intake from needs in children will be stored in fat (Kharismawati, 2011).

The majority of fat intake in school-aged children is lacking. It happens because the intake of fat consumed is only limited to fried and stir-fried foods (Rauf, Dewi, \& Syafei, 2015). In this study, students got fat intake from foods that were processed by frying. Fat has a function that is the reserve of energy in the body. At one gram of fat is the same as containing nine calories. The contribution of energy from fat for children aged $5-18$ years is around $30 \%$ of the total body needs (Hardiansyah \& Napitupulu, 2013). The need for fat intake for children aged 7-9 years is 72 grams, for female aged $10-12$ years old is 67 grams, and for male aged 10 12 years old is 70 grams. Lack of consumption of fat intake can cause a reduction in energy availability because energy must be fulfilled, so a catabolism/protein breakdown process occurs. If it continues, fat reserves will decrease and result in weight loss (Manuhutu, Purnamasari, \& Dardjito, 2017).

The majority of vitamin intake in school-aged children experiences less intake. It is due to the lack 
of consumption of fruits and vegetables in schoolage children. In this study, not all vitamin content in fruits and vegetables was seen because it adjusted to the results or vitamin content contained in the software used. Vitamins are organic substances that are needed by the body, and together with enzymes are useful in the process of metabolism and conversion of proteins and carbohydrates into energy. Vitamins have a role in several stages of the reaction of energy metabolism, growth, and maintenance of the body (Rahmawati, 2012). The need for good vitamins for school-age children aged 7-9 years is $55.5 \mathrm{mg}$, while for females aged 10-12 years is $65 \mathrm{mg}$, and for males, there is $65.3 \mathrm{mg}$ (Almatsier, 2010). These vitamin intake needs are based on the sum of vitamins A, B1, B2, B3, B6, C, and $E$, at each age (Almatsier, 2010). Each vitamin has its function.

All school-age children in this study experienced insufficient mineral intake. It can be caused by the lack of respondents' intake of plant foods. Minerals are parts of the body that play an essential role in maintaining body functions at the cellular, tissue, and organ levels. Besides, minerals also play a role in the metabolic stage. The mineral is one of the micronutrient substances needed by the body and has a different function between one mineral and the other minerals. The best mineral source is animal food, except magnesium, which is more abundant in plant foods (Almatsier, 2010). Mineral needs for children aged 7-9 years, namely 7341 grams, for males aged $10-12$ years is 8577 grams, and for females aged $10-12$ years is 8588 grams. Minerals that are important for school-age children are iron, calcium, and zinc, and if these minerals are lacking, it can cause disruption to children's growth and development, children's performance at school, and experience diseases, such as iron deficiency anemia (Sari, Juffrie, Nurani, \& Sitaresmi, 2016). Mineral intake requirements differ for each age and depend on the mineral type.

Nursing implications related to the results of the research are that nurses must pay attention to nutritional needs, especially in school-age children, because nutritional needs are basic human needs. This study presents the characteristics of each nutrient intake based on the nutritional status of children. These data make it easy for nurses to develop more specific intervention plans related to a nutrient deficiency in school-age children.

\section{CONCLUSION}

The nutritional status of respondents in this study mostly had normal nutritional status, with a number of 57 students (67.9\%). The most nutrient intake based on nutritional status was the intake of carbohydrates, fats, vitamins, and minerals. The category of more protein intake in the normal nutritional status was 34 students (40.5\%). Calorie intake based on the nutritional status of respondents, in this study, had less calorie intake, and most experienced by children with normal nutritional status, with the number of 43 students (51.2\%).

\section{REFERENCES}

Adriani, M., \& Wirjatmadi, B. (2012). Peranan gizi dalam siklus kehidupan. Jakarta: Kencana prenada media group .

Alatas, S. S. (2011). Status gizi anak usia sekolah (712 tahun) dan hubungannya dengan tingkat asupan kalsium harian di Yayasan Kampung Kids Pejaten Jakarta Selatan. Skripsi, Universitas Indonesia, Jakarta.

Almatsier, Sunita. (2010). Prinsip dasar ilmu gizi. Jakarta: PT. Gramedia Pustaka Utama.

Hardinsyah, R. H., \& Napitupulu, V. (2012).Kecukupan Energi, Protein, Lemak dan Karbohidrat. Departemen Gizi Masyarakat FEMA IPB dan Departemen GIZI FIK UI. Bogor

Hidayati, R. N. (2014). Hubungan Asupan Makanan Anak dan Status Ekonomi Keluarga dengan Status Gizi Anak Usia Sekolah di Kelurahan Tugu Kecamatan Cimanggis Kota Depok. Jurnal Keperawatan Bina Sehat, 6(2).

Iklima, N. (2017). Gambaran pemilihan makanan jajanan pada anak usia sekolah dasar. Jurnal Keperawatan BSI, 5(1), 8-17

Irmilia, E., Herlina., \& Hasneli, Y. (2013). Hubungan peran orang tua terhadap perkembangan psikososial anak usia sekolah. Jurnal Online Mahasiswa, 2 (1), 551-557.

Karaki, K., Kundre, R., \& Karundeng, M. (2016). Hubungan pola asuh ibu dengan perilaku sulit makan pada anak usia prasekolah (3-5 tahun) di Taman Kanak-Kanak Desa Palelon Kec. Modoinding Minahasa Selatan. ejournal Keperawatan (e-Kp), 4(1), 1-7.

Ministry of Health of the Republic of Indonesia. (2013). Riset kesehatan dasar 2013. Jakarta 


\section{NUNGSINING \\ PRACTICES}

Ministry of Health of the Republic of Indonesia (2019). Profil kesehatan Indonesia 2018. Jakarta

Kharismawati, R. (2011). Hubungan tingkat asupan energi, protein, lemak, karbohidrat dan serat dengan status obesitas pada siswa SD. Skripsi. Program Studi IImu Gizi FK Undip. Semarang

Latifah, R.A., (2015). Hubungan asupan makanan dan ekonomi keluarga dengan status gizi pada anak usia sekolah di SD Muhammadiyah Ambarketawang 3. Skripsi Universitas Muhammadiyah Yogyakarta. Yogyakarta.

Lestari, I. D., Ernalia, Y., \& Restuastuti, T. (2016). Gambaran Status Gizi Pada Siswa Sekolah Dasar Kecamatan Bangko Kabupaten Rokan Hilir. Jurnal Online Mahasiswa Fakultas Kedokteran Universitas Riau, 3(2), 1-14.

Manuhutu, R., Purnamasari, D. U., \& Dardjito, E. (2017). Pengaruh Tingkat Konsumsi Energi, Protein, Lemak, dan Status Kecacingan terhadap Status Gizi pada Siswa Sekolah Dasar Negeri 01 Limpakuwus. Kesmas Indonesia, 9(1), 46-55.

Marisa, M., \& Nuryanto, N. (2014). Pengaruh pendidikan gizi melalui komik gizi seimbang terhadap pengetahuan dan sikap pada siswa SDN Bendungan di Semarang. Journal of Nutrition College, 3(4), 925-932.

Rahman, N., Dewi, N., \& Bohari. (2017). Kebiasan sarapan pagi, asupan gizi dan status gizi murid SDN Inpres 3 Tondo, Kota Palu. Jurnal Preventif, 8 (1), 14-20

Rahmawati, M. (2012). Hubungan antara asupan vitamin dan mineral dengan morbiditas pada siswa di SMPN 5 Bogor dan SMPN 2 Cibinong. Skripsi. Institut Pertanian Bogor. Bogor
Rauf, S., Dewi, T., \& Syafei, A. (2015). Gambaran asupan zat gizi makro dan status gizi anak SD Inpres Pajjaiyang Kelurahan Sudiang Raya Kecamatan Biringkanaya Kota Makassar. Media Gizi Pangan, 19(1).

Sari, E. M., Juffrie, M., Nuraini., Sitaresmi, M. N., (2016). Asupan protein, kalsium dan fosfor pada anak stunting dan tidak stunting usia 24-59 bulan. Jurnal Gizi Klinik Indonesia, 12 (4), 152-159.

Siregar, Y. H. W., Ernalia, Y., \& Restuastuti, T. (2016). Gambaran Status Gizi pada Siswa Sekolah Dasar di Desa Teluk Kiambang Kecamatan Tempuling Kabupaten Indragiri Hilir. Jurnal Online Mahasiswa Fakultas Kedokteran Universitas Riau, 3(2), 1-13.

Soetjiningsih., \& Ranuh, I.G.N.G., (2014) Tumbuh Kembang Anak Edisi 2. Jakarta: EGC.

Utari, L. D., Ernalia, Y., \& Suyanto, S. Gambaran Status Gizi dan Asupan Zat Gizi pada Siswa Sekolah Dasar Kecamatan Sungai Sembilan Kota Dumai. Jurnal Online Mahasiswa Fakultas Kedokteran Universitas Riau, 3(1), 1-17.

Varricchio, C. G., Frank-Stromborg, M., \& Olsen, S. J. (2004). Instruments for Clinical Health Research. $3^{\text {rd }}$ Edition. Canada. Jones and Bartlett Publishers.

Warkentin, S., Mais, L. A., Carnell, S., Latorre, M. R., \& Taddei, J. A. A. C. (2018). Parents matter: associations of parental bmi and feeding behaviors with child BMI in Brazilian preschool and school-aged children. Frontiers in Nutrition. 5 (69). 